\title{
Design and Optimisation of Wastewater Treatment Plant for the Poultry Industry
}

\author{
Rui MA ${ }^{1}$, Chien Hwa Chong ${ }^{2 *}$, and Dominic C. Y. FoO ${ }^{1}$ \\ ${ }^{1}$ Department of Chemical and Environmental Engineering/Centre of Excellence for Green Technologies, University of Nottingham \\ Malaysia, Broga Road, 43500 Semenyih, Selangor, Malaysia \\ ${ }^{2}$ School of Engineering and Physical Sciences, Heriot-Watt University Malaysia, Putrajaya, Malaysia
}

\begin{abstract}
The objective of this study is to optimise the wastewater treatment plant of poultry industry. The optimisation of simulation model was done using the SuperPRO designer as simulator. The performance of the wastewater treatment plant for the poultry industry has improved significantly at the minimum cost. The COD value reduced from $133 \mathrm{mg} / \mathrm{L}$ to $0.05 \mathrm{mg} / \mathrm{L}$ at the discharge stream 1 and $73.7 \mathrm{mg} / \mathrm{L}$ for discharge stream 2. In addition, the BOD5 value reduced from $66.7 \mathrm{mg} / \mathrm{L}$ to $0.03 \mathrm{mg} / \mathrm{L}$ at the discharge stream 1 and $47.1 \mathrm{mg} / \mathrm{L}$ at the discharge stream 2. Further to this, the TTS reduced from $33.3 \mathrm{mg} / \mathrm{L}$ to $0.0 \mathrm{mg} / \mathrm{L}$ at the discharge stream 1 and $1.69 \mathrm{mg} / \mathrm{L}$ at the discharge stream 2 . Oil and grease also reduced from $3.3 \mathrm{mg} / \mathrm{L}$ to 0.024 $\mathrm{mg} / \mathrm{L}$ at the discharge stream 1 and $18.7 \mathrm{mg} / \mathrm{L}$ at the discharge stream 2 . The existing model and system can improve the wastewater treatment plant of poultry industry.
\end{abstract}

\section{Introduction}

The government has set the discharge standards of effluents in Environmental Quality (Industrial and Sewage Effluents) Regulations 2009. The values of total suspended solids (TSS), COD, BOD5, nitrate nitrogen and oil and grease should be less than or equal to 100 , $200,50,50$, and $10 \mathrm{mg} / \mathrm{L}$ respectively to reach standard B. Those should be less than or equal to 50, 120, 20, 20 and $5 \mathrm{mg} / \mathrm{L}$ respectively to reach standard A (Department of Environment, 2009).

Plants built before 2009 need to comply with the rules and regulation set by the DOE. A poultry industry with a wastewater treatment plant was selected in this study. The existing wastewater treatment plant was designed to discharge $72 \mathrm{~m}^{3} /$ day of effluent. The TSS, COD, BOD5, oil and grease set for the designed are 33.3, 133, 66.7 and $3.3 \mathrm{mg} / \mathrm{L}$, respectively. The plant consists of an oil and grease separation, an equalisation, a flocculation tank, a coagulation tank, a dissolved air floatation unit, an activated sludge reactor, a clarifier and a filter press. In this process, it consists of a recycle stream connected from the filter press to the equalisation tank. The existing plant efficiency has high potential to improve by re-designing the process by optimising the recycle ration.

Will the discharge stream reduced or performed better after optimisation and what is the best design to optimise the process? A simulation model was established to improve the performance of the wastewater treatment plant. The poultry wastewater treatment system was simulated through the SuperPro
Designer, and the performance was improved based on the existing wastewater treatment plant shown in Figure 1 with purchasing of an activated sludge reactor, a clarifier, a storage tank and a belt filter only but remaining the rest of the plant.

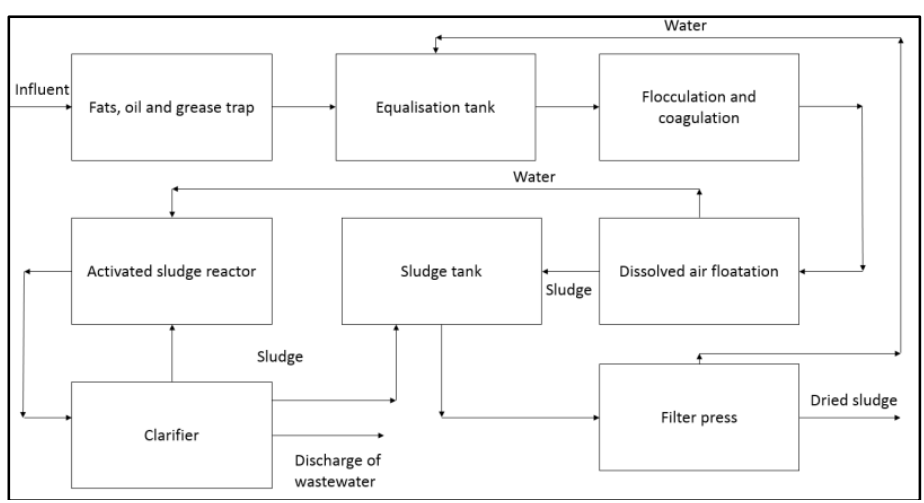

Figure 1. Flow diagram of the existing wastewater treatment plant

\section{Poultry Wastewater Treatment Design}

\subsection{Wastewater treatment with recycling}

SuperPro Designer has been applied for design, process analysis, evaluation and optimisation of the poultry wastewater treatment. Since in reality, the average flow to the wastewater treatment is $72 \mathrm{~m}^{3} /$ day and the operation time is eight hours per day. Thus, in the

Corresponding author: chongchienhwa@gmail.com 
simulation modelling, the average flow of the influent to the treatment process flowrate was set as $3.0 \mathrm{~m}^{3} / \mathrm{h}$ and operated for 24 hour per day as the process operation mode was continuous. A minor modification based on the exiting model and the real wastewater treatment plan where the water from the belt filtration is not recycled to the equalisation tank. This stream does not help in reducing the environmental properties, but it requires larger operating cost and larger equipment.

\subsection{Influent stream and mass balance}

The input stream to the wastewater treatment plant was supplied at $30^{\circ} \mathrm{C}$ and atmospheric pressure. It consists of sludge, ammonia, water and carbon dioxide. In this case, the average flowrate of the influent is $3.0 \mathrm{~m}^{3} / \mathrm{h}$. The components in influent stream, their flow rates and concentrations are shown in Table 1.

In the mass balance calculation, different recycle ratio was set to check the environmental properties in the discharge streams. The sass in was the sum of mass of influent, polymer, air to DAF and water to belt filter. For mass out, it was the sum of mass of oil and grease, S-104, discharge stream 1, discharge stream 2 and sludge.

Table 1. Details of the influent stream

\begin{tabular}{cccc}
\hline Components & $\begin{array}{c}\text { Flowrate } \\
\mathbf{( k g / h )}\end{array}$ & $\begin{array}{c}\text { Mass } \\
\text { Composition } \\
\mathbf{( \% )}\end{array}$ & $\begin{array}{c}\text { Concentration } \\
\left(\mathbf{k g} / \mathbf{m}^{\mathbf{3}} \mathbf{)}\right.\end{array}$ \\
\hline Carbon & 0.1400 & 0.0051 & 0.0481 \\
Dioxide & & & \\
Ammonia & 0.0600 & 0.0021 & 0.0198 \\
Dom Waste & 0.1500 & 0.0052 & 0.0491 \\
Water & 2830 & 99.95 & 943.5 \\
FSS & 0.0300 & 0.0010 & 0.0094 \\
TDS & 0.8700 & 0.0306 & 0.2888 \\
X-VSS-h & 0.0300 & 0.0010 & 0.0094 \\
X-VSS-n & 0.0300 & 0.0010 & 0.0094 \\
X-VSS-i & 0.0200 & 0.0006 & 0.0057 \\
\hline
\end{tabular}

\subsection{Components registered}

Before starting the simulation, the components in database were added and those not in the database was registered with user defined components (Table 2).

Table 2. Component variables registered in the simulation

\begin{tabular}{|c|c|c|}
\hline Variables & User Defined & Definition \\
\hline $\begin{array}{l}\text { Carbon } \\
\text { Dioxide }\end{array}$ & No & $\begin{array}{c}\mathrm{CO}_{2} \text { or dissolved in the } \\
\text { form of } \mathrm{HCO}_{3} \text { or/and } \\
\mathrm{H}_{2} \mathrm{CO}_{3}\end{array}$ \\
\hline Ammonia & No & $\mathrm{NH}_{3}$ or dissolved $\mathrm{NH}_{4}$ \\
\hline DomWaste & Yes & Bio-degradable waste \\
\hline Water & No & Pure water \\
\hline Oxygen & No & $\begin{array}{l}\text { Oxygen diffused from } \\
\text { aeration/air supplied }\end{array}$ \\
\hline Nitrogen & No & $\begin{array}{c}\text { Product from } \\
\text { denitrification and air } \\
\text { supplied }\end{array}$ \\
\hline FSS & Yes & $\begin{array}{l}\text { Fixed Suspended solid } \\
\text { (non-degradable) }\end{array}$ \\
\hline $\mathrm{NO}_{3}$ & Yes & $\begin{array}{l}\text { Nitrate in whole } \\
\text { nitrification }\end{array}$ \\
\hline $\mathrm{NO}_{2}$ & Yes & $\begin{array}{l}\text { Nitrite in partial } \\
\text { nitrification }\end{array}$ \\
\hline TDS & Yes & $\begin{array}{l}\text { Non-biodegradable } \\
\text { dissolved solids }\end{array}$ \\
\hline X-VSS-h & Yes & $\begin{array}{l}\text { Active heterotrophic } \\
\text { biomass used in } \\
\text { denitrification }\end{array}$ \\
\hline X-VSS-n & Yes & $\begin{array}{l}\text { Active nitrifies } \\
\text { autotrophic biomass }\end{array}$ \\
\hline X-VSS-i & Yes & $\begin{array}{c}\text { Inert biomass represents } \\
\text { biomass decay }\end{array}$ \\
\hline
\end{tabular}

\subsection{Description of units and discharge streams}

Grit Chamber (GB - 101): The grit chamber removes part of the fixed suspended solids including fats, oil and grease from the influent. The grit chamber removes $70 \%$ of the solids.

Equalisation tank (EQ - 101): The equalisation tank functions like a 'buffer'. Even there is high flow fluctuation of the influent, the equalisation will still provide consist flow to the downstream treatment process. As the equalisation tank is in open air, there is no vented stream for the gases. An assumption is also

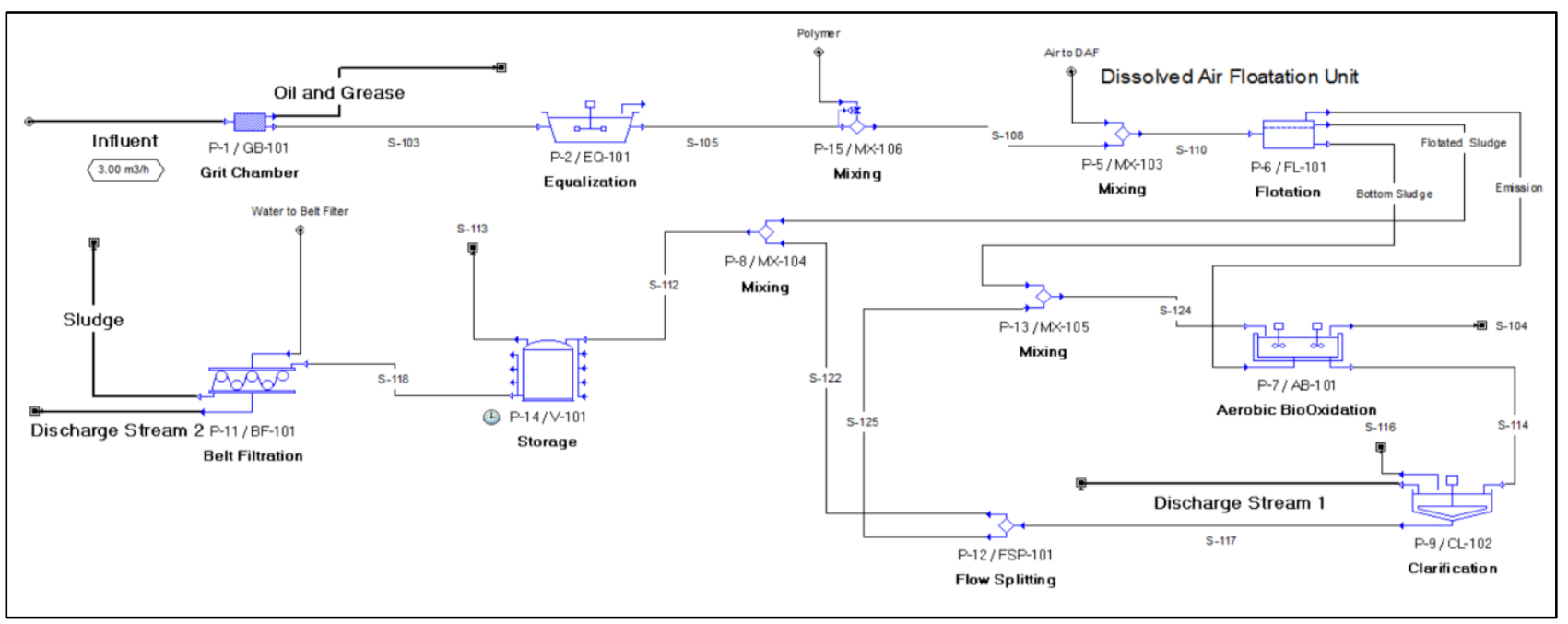

Figure 2. The flowsheet of the poultry wastewater treatment 
made that no reaction occurs in the equalisation tank (Auto Garment, 2018).

Mixer (MX - 106): The mixer is to mix the wastewater and polymer for flocculation and coagulation. This represents a simplified version of flocculation and coagulation unit.

Mixer (MX - 103): It represents part of the simplified dissolved air flotation unit. The mixer is to mix the wastewater and air supplied which can lift the suspended matters to the surface in the dissolved air flotation unit.

Flotation Unit (FL - 101): It represents part of the simplified dissolved air flotation (DAF) tank. This allows three layers to be separated; namely, top sludge, vented gases, and bottom sludge as shown in Figure 2. It is the demonstration of the results done DAF tank.

Mixer (MX - 105): The mixer is to mix the bottom sludge from DAF tank and the recycle stream from clarifier after the splitter.

Aerobic Reactor (AB-101): It represents the activated sludge reactor. The reactor converts ammonia into nitrite or nitrate. The vented gas from the flotation unit is being supplied that allows the reactions to occur for the treatment. Excessive nitrogen, oxygen and carbon dioxide are then emitted from the reactor.

Clarifier (CL -102): It clarifies the stream of $90 \%$ of sludge. After clarification, the wastewater is discharged, and small amount of carbon dioxide is emitted.

Flow Splitting (FSP - 101): The flow is then split two streams; one to recycle into the sludge reactor, one to storage tank. The splitting ratio to the bottom is equal to the recycle ratio to the activated sludge reactor, which plays an important role in optimising the wastewater treatment.

Mixer (MX - 104): The mixer is to mix the floated sludge from DAF tank and part of the downstream from clarifier.

Storage Tank (V - 101): The storage tank is whereby the floated sludge from DAF tank and the downstream from clarifier are collected.

Belt Filter (BF - 101): It is to separate the sludge and the liquid phase. Furthermore, a stream of water is used to help the separation. The sludge will be collected by agencies approved by Department of Environment, Malaysia.

Discharge Stream 1 and 2: They make up the effluent from the wastewater treatment plant. They are discharged into river directly. The concentration of each component were assessed and analysed. It was compared with the permissible values of discharge standards provided by the Environmental Quality Act 2009, Malaysia.

\subsection{Reactions in the activated sludge reactor}

There are five reactions occurred in the activated sludge reactor viz. autotrophic biomass decay reaction, heterotrophic biomass decay reaction, denitrification, domwaste degradation and full nitrification are shown in Table 3, 4, 5, 6 and 7, respectively. These reactions are described as follows with their mass-based stoichiometry (Waheed, 2010):
Autotrophic Biomass (X-VSS-n) Decay Reaction:

$\mathrm{X}-\mathrm{VSS}-\mathrm{n}+\mathrm{O}_{2} \rightarrow \mathrm{NH}_{3}+\mathrm{CO}_{2}+\mathrm{H}_{2} \mathrm{O}+\mathrm{X}-\mathrm{VSS}-\mathrm{i}$

Table 3. Autotrophic Biomass (X-VSS-n) Decay Reaction

\begin{tabular}{ccccccc}
\multicolumn{2}{c}{ Reaction } & & & & & \\
& $\begin{array}{c}\mathbf{X}- \\
\text { VSS- } \\
\text { n }\end{array}$ & $\mathbf{O}_{2}$ & $\mathbf{N H}_{3}$ & $\mathbf{C O}_{2}$ & $\mathbf{H}_{2} \mathbf{O}$ & $\begin{array}{c}\mathbf{X}- \\
\text { VSS- } \\
\mathbf{i}\end{array}$ \\
\hline Mass & 1.05 & 1.15 & 0.1 & 1.45 & 0.45 & 0.20
\end{tabular}

Stoichiometry/g

Heterotrophic Biomass (X-VSS-h) Decay Reaction $\mathrm{X}$-VSS-h $+\mathrm{O}_{2} \rightarrow \mathrm{NH}_{3}+\mathrm{CO}_{2}+\mathrm{H}_{2} \mathrm{O}+\mathrm{X}$-VSS-i

Table 4. Heterotrophic Biomass (X-VSS-h) Decay Reaction

\begin{tabular}{ccccccc}
\hline Component & $\begin{array}{c}\mathbf{X}- \\
\text { VSS- } \\
\text { h }\end{array}$ & $\mathbf{O}_{2}$ & $\mathbf{N H}_{3}$ & $\mathbf{C O}_{2}$ & $\mathbf{H}_{2} \mathbf{O}$ & $\begin{array}{c}\mathbf{X}- \\
\text { VSS- } \\
\text { i }\end{array}$ \\
\hline $\begin{array}{c}\text { Mass } \\
\text { Stoichiometry/g }\end{array}$ & 1.05 & 1.15 & 0.1 & 1.45 & 0.45 & 0.20 \\
\hline
\end{tabular}

Denitrification

DomWaste $+\mathrm{NO}_{3} \rightarrow \mathrm{CO}_{2}+\mathrm{N}_{2}+\mathrm{H}_{2} \mathrm{O}+\mathrm{X}$-VSS-h

Table 5. Denitrification

\begin{tabular}{ccccccc}
\hline Component & $\begin{array}{c}\text { Dom } \\
\text { Waste }\end{array}$ & $\begin{array}{c}\text { NO } \\
\mathbf{3}\end{array}$ & $\mathbf{C O}_{2}$ & $\mathbf{N}_{2}$ & $\mathbf{H}_{2} \mathbf{O}$ & $\begin{array}{c}\text { X- } \\
\text { VSS- } \\
\text { h }\end{array}$ \\
\hline $\begin{array}{c}\text { Mass } \\
\text { Stoichiometry/g }\end{array}$ & 34.6 & 108 & 48 & 17 & 61.4 & 16.2 \\
\hline
\end{tabular}

DomWaste Degradation

DomWaste $+\mathrm{NH}_{3}+\mathrm{O}_{2} \rightarrow \mathrm{X}$-VSS-h $+\mathrm{H}_{2} \mathrm{O}+\mathrm{CO}_{2}$

Table 6. DomWaste Degradation

\begin{tabular}{ccccccc}
\hline Component & $\begin{array}{c}\text { Dom } \\
\text { Waste }\end{array}$ & $\begin{array}{c}\mathrm{NH}^{3} \\
\mathbf{3}\end{array}$ & $\mathbf{O}_{2}$ & $\begin{array}{c}\mathrm{X}- \\
\text { VS } \\
\text { S-h }\end{array}$ & $\mathbf{H}_{2} \mathbf{O}$ & $\mathbf{C O}_{2}$ \\
\hline $\begin{array}{c}\text { Mass } \\
\text { Stoichiometry/g }\end{array}$ & 1 & 0.1 & 1.4 & 0.8 & 0.8 & 0.9 \\
\hline
\end{tabular}

Full nitrification

$\mathrm{NH}_{3}+\mathrm{O}_{2}+\mathrm{CO}_{2} \rightarrow$ X-VSS-n $+\mathrm{H}_{2} \mathrm{O}+\mathrm{NO}_{3}$

Table 7. Full nitrification

\begin{tabular}{ccccccc}
\hline Component & $\mathbf{N H}_{3}$ & $\mathbf{O}_{2}$ & $\mathbf{C O}_{2}$ & $\begin{array}{c}\mathrm{X}- \\
\text { VSS- } \\
\text { n }\end{array}$ & $\mathbf{H}_{2} \mathbf{O}$ & $\mathrm{NO}_{3}$ \\
\hline $\begin{array}{c}\text { Mass } \\
\begin{array}{c}\text { Stoichiometry/ } \\
\text { g }\end{array}\end{array}$ & 7.5 & 29.46 & 2.19 & 1.12 & 11.29 & 26.74 \\
\hline
\end{tabular}

\section{Costing and Optimisation}

The capital cost mainly consisted of the purchased cost of the active sludge reactor, the clarifier, the storage tank and the belt filter were investigated and analysed. Existing units like the grit chamber, the equalisation tank, the DAF tank were not considered as capital cost as these are existing units. The unit cost was estimated based on equation (1). 


$$
\alpha_{2}=\alpha_{1}\left(\frac{\beta_{2}}{\beta_{1}}\right)^{\gamma}
$$

Where $\alpha$ is cost of equipment, $\beta$ is size of equipment and $\gamma$ is size exponents. The size exponents were 1.03, 0.6, 0.3 with respect to the clarifier tank, the sludge reactor and the storage tank, respectively (Donald, 1989). Similarly, equation (2), (3) and (4):

$$
P_{2}=P_{1}\left(\frac{\beta_{2}}{\beta_{1}}\right)^{\gamma}
$$

Where $P$ is power of equipment. The power of the rest system was assumed to be $1.0 \mathrm{kWh}$. Assumption made were the operation duration set at 350 days per year, and 24 hour per day. The total amount of wastewater calculated based on the flowrate of influent of $3.0 \mathrm{~m}^{3} / \mathrm{h}$.

$$
\theta=\frac{i(1+i)^{n}}{(1+i)^{n}-1}
$$

Where $\theta$ is the annualised factor, $i$ is the interest rate per year, and $n$ is the number of years of the duration to borrow money.

$$
C_{F}=f_{I} \sum_{i} C_{E, i}
$$

Where $C_{F}$ is the installed capital cost, $f_{I}$ is the overall installation factor which is 5.8 in this case and $C_{E, i}$ is the capital cost for the equipment $i$ (Smith, 2005). So, the total annualised cost, $C_{T}$ is shown in equation (5).

$$
C_{T}=C_{F} \theta
$$

By assuming the duration to return money to be 30 years, the interest rate is $7.4 \%$ taken from HSBC official website (Business.hsbc.uk, 2019). For maintenance cost, the annual maintenance was calculated by multiplying a maintenance factor 5\% with the capital cost. Then, the

\begin{tabular}{|c|c|c|c|c|c|c|c|c|}
\hline \multirow{2}{*}{$\begin{array}{l}\text { Recycle } \\
\text { Ratio/\% }\end{array}$} & \multicolumn{4}{|c|}{ Inlet of the Reactor (S-124) } & \multicolumn{4}{|c|}{ Outlet of the Reactor (S-114) } \\
\hline & $\begin{array}{l}\text { Oil and } \\
\text { Grease }\end{array}$ & COD & BOD $_{5}$ & TSS & $\begin{array}{l}\text { Oil and } \\
\text { Grease }\end{array}$ & COD & BOD $_{5}$ & TSS \\
\hline 95 & 5.72 & 927 & 518 & 646 & 5.63 & 847 & 461 & 662 \\
\hline 90 & 2.89 & 590 & 336 & 379 & 2.84 & 522 & 285 & 405 \\
\hline 80 & 1.46 & 350 & 206 & 182 & 1.43 & 291 & 161 & 213 \\
\hline 70 & 0.980 & 297 & 188 & 78.9 & 0.950 & 258 & 158 & 98.9 \\
\hline 60 & 0.740 & 263 & 173 & 30.6 & 0.720 & 244 & 159 & 36.8 \\
\hline 50 & 0.590 & 218 & 145 & 20.1 & 0.570 & 204 & 135 & 23.5 \\
\hline 40 & 0.500 & 185 & 123 & 15.2 & 0.480 & 174 & 115 & 17.6 \\
\hline 30 & 0.430 & 160 & 107 & 12.4 & 0.410 & 151 & 100 & 14.1 \\
\hline 20 & 0.370 & 141 & 94.2 & 10.5 & 0.360 & 134 & 88.9 & 11.9 \\
\hline 10 & 0.330 & 126 & 84.3 & 9.10 & 0.320 & 120 & 79.7 & 10.3 \\
\hline 0 & 0.300 & 114 & 76.3 & 8.10 & 0.290 & 109 & 72.3 & 9.10 \\
\hline
\end{tabular}
total maintenance obtained by multiplying the number of years.

\section{Results and Discussion}

Table 8. Oil and Grease, COD, $\mathrm{BOD}_{5}$ and TSS at the inlet and outlet of the activated sludge reactor 
Table 9. Oil and Grease, $\mathrm{COD}, \mathrm{BOD}_{5}$ and TSS at the inlet and outlet of the clarifier tank

\begin{tabular}{ccccccccc}
\hline $\begin{array}{c}\text { Recycle } \\
\text { Ratio/\% }\end{array}$ & \multicolumn{2}{c}{ Inlet of the Clarifier Tank (S-114) } & \multicolumn{4}{c}{ Outlet of the Clarifier Tank (Discharge stream 1) } \\
\cline { 2 - 8 } & $\begin{array}{c}\text { Oil and } \\
\text { Grease/ppm }\end{array}$ & $\begin{array}{c}\text { COD } \\
\text { /ppm }\end{array}$ & $\begin{array}{c}\text { BOD } \\
\text { /ppm }\end{array}$ & $\begin{array}{c}\text { TSS } \\
\text { /ppm }\end{array}$ & $\begin{array}{c}\text { Oil and } \\
\text { Grease/ppm }\end{array}$ & $\begin{array}{c}\text { COD } \\
\text { /ppm }\end{array}$ & $\begin{array}{c}\text { BOD } \\
\text { /ppm }\end{array}$ & $\begin{array}{c}\text { TSS } \\
\text { /ppm }\end{array}$ \\
\hline 95 & 5.63 & 847 & 461 & 662 & 0.006 & 0.900 & 0.490 & 0.703 \\
90 & 2.84 & 522 & 285 & 405 & 0.003 & 0.540 & 0.290 & 0.419 \\
80 & 1.43 & 291 & 161 & 213 & 0.001 & 0.280 & 0.150 & 0.220 \\
70 & 0.950 & 258 & 158 & 99.0 & 0.001 & 0.140 & 0.080 & 0.102 \\
60 & 0.720 & 244 & 159 & 37.0 & 0.001 & 0.070 & 0.040 & 0.038 \\
50 & 0.570 & 204 & 135 & 24.0 & 0.001 & 0.050 & 0.030 & 0.024 \\
40 & 0.480 & 174 & 115 & 18.0 & 0.001 & 0.040 & 0.020 & 0.018 \\
30 & 0.410 & 151 & 100 & 14.0 & N.A. & 0.030 & 0.020 & 0.015 \\
20 & 0.360 & 134 & 89.0 & 12.0 & N.A. & 0.030 & 0.020 & 0.012 \\
10 & 0.320 & 120 & 80.0 & 10.0 & N.A. & 0.020 & 0.010 & 0.011 \\
0 & 0.300 & 109 & 106 & 9.00 & N.A. & 0.020 & 0.010 & 0.009 \\
\hline
\end{tabular}

*N.A. Not applicable as it is too close to zero.

\subsubsection{Belt filter}

A minor modification was made in the exiting design model compared to the real wastewater treatment plant where the water from the belt filtration was not recycled to the equalisation tank. It was found that water discharged at this stream does not help in reducing the environmental properties but required larger operating cost and equipment. Referring to Table 10 , it shows the discharge properties of $\mathrm{COD}, \mathrm{BOD}_{5}$, oil and grease, TSS and $\left(\mathrm{NO}_{3} / \mathrm{NO}_{2}\right)$ when the recycle ratio changed from 0 to $95 \%$. The setting of recycle ratio above $50 \%$ is not acceptable as the $\mathrm{BOD}_{5}$ exceeded the parameter limits of effluent of Standard B set by the Malaysia Environment Quality (Sewage and Industrial Effluents) Regulations. The recycle ratio below $60 \%$ is acceptable as the $\mathrm{BOD}_{5}$ value ranged from 26.5 to 47.1 from 0 to $50 \%$. Further to this, the COD limit set by the local authority is less than 100 $\mathrm{ppm}$ for standard B. Therefore, any settings above the recycle ratio of $70 \%$ exceed the limit as it is ranged

\subsection{Economic Evaluation after optimisation}

Clarifier tank, activated sludge reactor and storage tanks cost and sizes are shown in Table 11. The cost of a clarifier tank, activated sludge reactor and storage tank are around RM $80 \mathrm{k}, \mathrm{RM} 350 \mathrm{k}$ and RM $9.0 \mathrm{k}$, respectively based on the calculated size based on different volume. Referring to the simulation results, the cost of treating wastewater per $\mathrm{m}^{3}$ of water based on the existing design reduced from RM $105 / \mathrm{m}^{3}$ to RM $14.8 / \mathrm{m}^{3}$ when the years to run reduced close to 10 years. The costs to treat ranged from RM $8 / \mathrm{m}^{3}$ to RM 11/ $\mathrm{m}^{3}$ for the remaining years. This calculated annualised capital cost and operating cost including the sum of charge for the disposal of sludge, the oil and grease sent for landfill, the cost of annual polymer used for coagulation and flocculation, the annual labour cost, the annual electricity, and the water utility to the belt filter are shown in Table 12. from 105 to $230 \mathrm{ppm}$ from 80 to $95 \%$ recycle ratio. For oil and grease, all values below $10 \mathrm{ppm}$, therefore, it is acceptable. Detail flowrate of sludge and water to belt filter are shown in Appendix 1.

Table 10. Environment properties of the discharge streams for different recycle ratios

\begin{tabular}{|c|c|c|c|c|c|}
\hline \multirow{2}{*}{$\begin{array}{l}\text { Recycle } \\
\text { Ratio/\% }\end{array}$} & \multicolumn{5}{|c|}{ Discharge Stream 2 (ppm) } \\
\hline & COD & BOD5 & $\begin{array}{c}\text { Oil } \\
\text { and } \\
\text { Grease }\end{array}$ & TSS & $\left(\mathrm{NO}_{3} / \mathrm{NO}_{2}\right)$ \\
\hline 95 & 230 & 125 & 9.93 & 187 & 0.226 \\
\hline 90 & 165 & 90.0 & 6.31 & 133 & 0.196 \\
\hline 80 & 105 & 57.9 & 3.72 & 81.3 & 0.202 \\
\hline 70 & 92.6 & 55.4 & 2.65 & 45.8 & 0.338 \\
\hline 60 & 86.4 & 54.7 & 2.06 & 24.9 & 1.10 \\
\hline 50 & 73.7 & 47.1 & 1.69 & 18.7 & 1.87 \\
\hline 40 & 63.7 & 40.8 & 1.44 & 15.3 & 2.47 \\
\hline 30 & 56.0 & 36.0 & 1.25 & 13.0 & 2.83 \\
\hline 20 & 49.9 & 32.1 & 1.11 & 11.4 & 2.99 \\
\hline 10 & 45.1 & 29.0 & 1.00 & 10.1 & 2.99 \\
\hline 0 & 41.1 & 26.5 & 0.910 & 9.10 & 2.91 \\
\hline
\end{tabular}

The recycle ratio affected the total annual cost. Figure 3 shows the changed of total cost at recycle ratio. The recycle ration increase slightly when the recycle ration set at $10 \%$. Then, it decreased drastically from RM 140 thousand to around RM 134 thousand. It became constant when the recycle ratio ranged from 20 to $95 \%$. This could be due to the change of the volume of the sludge storage tank. It decreased when more sludge discharged with the effluents and the tank become smaller. In addition, the production of the sludge from the belt filter and the water utility applied to the belt filtration decrease as recycle ratio increases and resulted in less cost spent in sending sludge to landfill and paying for water bill. 
Table 11. Different volume and price of the influenced units at different recycle ratio

\begin{tabular}{|c|c|c|c|c|c|c|}
\hline $\begin{array}{l}\text { Recycle } \\
\text { ratio/\% }\end{array}$ & $\begin{array}{c}\text { Clarifier } \\
\text { Tank Volume } \\
/\left(\mathbf{m}^{3}\right)\end{array}$ & $\begin{array}{c}\text { Cost for } \\
\text { Clarifier Tank } \\
\text { /RM thousand }\end{array}$ & $\begin{array}{l}\text { Activated Sludge } \\
\text { Reactor Volume / } \\
\qquad\left(\mathbf{m}^{\mathbf{3}}\right)\end{array}$ & $\begin{array}{l}\text { Cost for Activated } \\
\text { Sludge Reactor } \\
\text { /RM thousand }\end{array}$ & $\begin{array}{c}\text { Storage } \\
\text { Tank } \\
\text { Volume / } \\
\left(\mathbf{m}^{3}\right)\end{array}$ & $\begin{array}{c}\text { Cost for Storage } \\
\text { Tank /RM } \\
\text { thousand }\end{array}$ \\
\hline 95 & 6.75 & 79.4 & 12.6 & 348 & 0.84 & 4.17 \\
\hline 90 & 6.74 & 79.2 & 12.5 & 346 & 1.46 & 4.92 \\
\hline 80 & 6.72 & 79.0 & 12.4 & 345 & 2.7 & 5.92 \\
\hline 70 & 6.7 & 78.7 & 12.4 & 345 & 3.92 & 6.62 \\
\hline 60 & 6.68 & 78.5 & 12.4 & 344 & 5.14 & 7.18 \\
\hline 50 & 6.66 & 78.2 & 12.3 & 343 & 6.34 & 7.65 \\
\hline 40 & 6.64 & 78.0 & 12.3 & 343 & 7.54 & 8.06 \\
\hline 30 & 6.62 & 77.8 & 12.2 & 342 & 8.73 & 8.42 \\
\hline 20 & 6.6 & 77.5 & 12.2 & 341 & 9.92 & 8.75 \\
\hline 10 & 6.59 & 77.4 & 12.1 & 341 & 11.1 & 9.05 \\
\hline 0 & 6.57 & 77.1 & 12.1 & 340 & 12.27 & 9.32 \\
\hline
\end{tabular}

Table 12. Cost of treating wastewater per $\mathrm{m}^{3}$ of water

\begin{tabular}{ccccccc}
\hline $\begin{array}{l}\text { Years } \\
\text { to run }\end{array}$ & $\begin{array}{l}\text { Installed } \\
\text { Capital Cost } \\
\text { /RM million }\end{array}$ & $\begin{array}{l}\text { Total } \\
\text { Maintenance } \\
\text { Cost/RM } \\
\text { thousand }\end{array}$ & $\begin{array}{l}\text { Total } \\
\text { Operating } \\
\text { Cost/ RM } \\
\text { million }\end{array}$ & $\begin{array}{l}\text { Total Cost to } \\
\text { Treat } \\
\text { Wastewater/ } \\
\text { RM }\end{array}$ & $\begin{array}{l}\text { Total Amount } \\
\text { of Wastewater } \\
\text { to Treat/ } \mathbf{m}^{\mathbf{3}} \\
\text { thousand }\end{array}$ & $\begin{array}{l}\text { Cost to Treat } \\
\text { per Volume of } \\
\text { Wastewater/ } \\
\left(\mathbf{R M} / \mathbf{m}^{\mathbf{3}}\right)\end{array}$ \\
\hline 1 & 2.53 & 21.8 & 0.097 & 2.65 & 25.2 & 105 \\
5 & 2.53 & 109 & 0.488 & 3.13 & 126 & 24.8 \\
10 & 2.53 & 218 & 0.984 & 3.73 & 252 & 14.8 \\
15 & 2.53 & 327 & 1.46 & 4.32 & 378 & 11.4 \\
20 & 2.53 & 436 & 1.95 & 4.92 & 504 & 9.76 \\
25 & 2.53 & 545 & 2.44 & 5.52 & 630 & 8.76 \\
30 & 2.53 & 654 & 2.92 & 6.11 & 756 & 8.09 \\
\hline
\end{tabular}

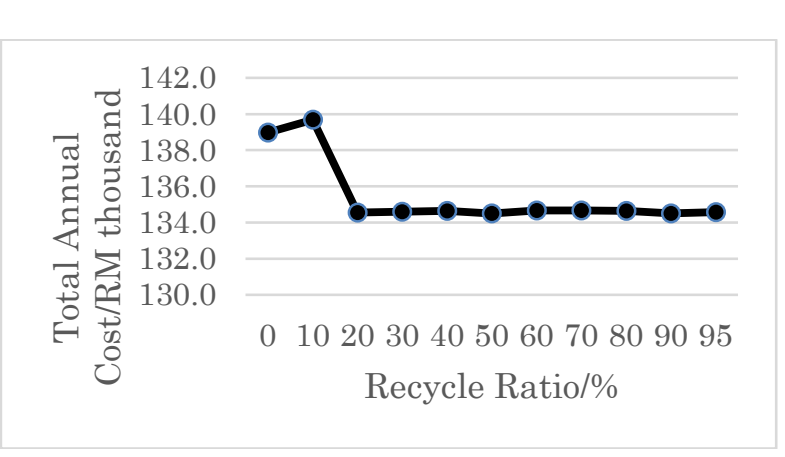

Figure 3. Total annual cost at different recycle ratio ranged from 0 to $100 \%$

The lowest total annual cost was RM 135 thousand at $50 \%$ and the highest total annual cost was RM 140 thousands at $90 \%$. Ensuring the discharge streams met discharge standards are important. Table 12 shows a

\section{Conclusions}

By optimising simulation model using the SuperPro Designer, performance of the wastewater treatment plant for the poultry industry can be predicted and the cost can be minimised. It can be seen from the huge reduction of COD from $133 \mathrm{mg} / \mathrm{L}$ to $0.049 \mathrm{mg} / \mathrm{L}$ for discharge stream 1 and $73.7 \mathrm{mg} / \mathrm{L}$ for discharge stream 2. A great reduction of $\mathrm{BOD}_{5}$ from $66.7 \mathrm{mg} / \mathrm{L}$ to 0.003 $\mathrm{mg} / \mathrm{L}$ for discharge stream 1 and $47.1 \mathrm{mg} / \mathrm{L}$ discharge stream 2 is also performed. TTS of $33.3 \mathrm{mg} / \mathrm{L}$ is reduced to $0.0 \mathrm{mg} / \mathrm{L}$ for discharge stream 1 and 1.69 $\mathrm{mg} / \mathrm{L}$ for discharge stream 2 . Oil and grease is also simulation $i$ with a recycle ratio of $50 \%$. For the optimal recycle ratio of $50 \%$, the environmental properties of the discharge streams met the discharge requirements compared to other settings showed in Table 10. The performance in terms of treating wastewater from the poultry industry with the minimum cost spent on operating and capital cost. The total capital cost of the units after recycle stream was about RM 31 thousand, the installed capital cost was RM 2.5 million after multiplying an installation factor of 5.8 (Smith, 2005). The cost of treating per volume of wastewater decreases significantly from year 1 to 10 . It is mainly because the annual installed capital cost. The annual installed cost decreases slowly with time after Year 10. Hence, the cost of treating a cubic metre wastewater also declines gradually. After year 20, it becomes stable around RM 9.8 per cubic metre of industry wastewater.

reduced from $3.30 \mathrm{mg} / \mathrm{L}$ to $0.024 \mathrm{mg} / \mathrm{L}$ for discharge stream 1 and $18.7 \mathrm{mg} / \mathrm{L}$ for discharge stream 2 . The discharge stream reduced or performed better after optimisation and the best design to optimise the process is setting the recycle ratio at $50 \%$. The process performance of the wastewater treatment plant for the poultry industry is improved significantly at the minimum cost. The total capital cost of the units after recycle stream was about RM 31 thousand and the installed capital cost was RM 2.5 million. Simulation and optimisation have been done based on the existing wastewater treatment plant of poultry industry, and 
good results have showed the practicability of the

\section{References}

Auto Garment; "What is Equalization Tank in Wastewater Treatment Plant," Auto Garment (2018) http://autogarment.com/equalization-tank-inwastewater-treatment

HSBC: Business Banking Interest Rates, https://www.business.hsbc.uk/en-gb/interestrates/interest-rates-finance-borrowing (2019)

Waheed, J.; Simulating a Novel Nitrogen Removal Process Using EnviroPro Designer, http://hdl.handle.net/10012/5201 (2010)

Donald, E. G.; Equipment Cost Estimating, Chemical Engineering Economics, 1st ed., pp. 8-21, Springer (1989)

Department of Environment, Ministry of Natural Resources and Environment: Environmental Requirements: A Guide For Investors, $11^{\text {th }}$ ed., http://www.doe.gov.my/eia/wpcontent/uploads/2012/03/A-Guide-For-Investors1.pdf (2010)

Smith, R.; Chemical Process Design and Integration, pp. 17-29, Wiley \& Sons, Chichester, U.K. (2005) system.

Appendix 1: The outlets of the wastewater treatment plant and the flowrate of water to the belt filter.

\begin{tabular}{cccc}
\hline Recycle ratio/\% & Production of Sludge/ $(\mathrm{kg} / \mathrm{hr})$ & Flowrate of Water to Belt Filter $\mathrm{m}^{3} / \mathrm{hr}$ & Discharge Stream $2 \mathrm{Flowrate} \mathrm{m}^{3} / \mathrm{hr}^{\circ}$ \\
95 & 0.499 & 3.025 & 0.009 \\
90 & 0.544 & 3.666 & 0.013 \\
80 & 0.653 & 4.394 & 0.023 \\
70 & 0.761 & 5.126 & 0.032 \\
60 & 0.862 & 5.804 & 0.041 \\
50 & 0.932 & 6.275 & 0.05 \\
40 & 0.993 & 6.69 & 0.059 \\
30 & 1.05 & 7.069 & 0.068 \\
20 & 1.10 & 7.421 & 0.076 \\
10 & 1.15 & 7.749 & 0.085 \\
0 & 1.20 & 8.057 & 0.094 \\
\hline
\end{tabular}

